\title{
DIFFERING HIV INFECTION RATES IN BRAZIL AND SOUTH AFRICA: A COMPARATIVE STUDY OF POLICIES AND PRACTICES
}

\section{Rafael Noronha, André de V Smit}

\section{INTRODUCTION}

During the past twenty years much attention has been focused on HIV/AIDS globally. Despite much research, endless discussions and political machinations, the pandemic is largely uncontrolled, particularly in parts of the developing world. However, some countries have managed to substantially reduce their rates of infection.

This limited study juxtaposes the post-1990 intervention strategies adopted by two developing countries, namely Brazil and South Africa, to reduce their respective infection rates. These countries are fairly similar and thus suitable for a comparative analysis.

While South Africa was singularly unsuccessful in its attempts to reduce the HIV infection rate, Brazil in contrast was much more successful. What did the Brazilians get right and what did the South Africans get wrong?

In order to illuminate the distinctive approaches adopted by the respective countries, a qualitative study with secondary data/policy analysis was conducted in Brazil and South Africa. The countries' profiles are succinctly presented and data on the comparative infection rates and analyses of the respective countries' HIV/AIDS policies are presented. These, together with the findings of in-depth interviews with directors of HIV/AIDS non-profit organizations based in Sao Paulo and Cape Town, reveal very different paths adopted by the two countries and hence their respective outcomes.

\section{COUNTRY PROFILES}

While Brazil and South Africa are dissimilar in some respects, there is also a growing resemblance. While some differences are reflected in Table 1, of importance here are the number of similarities, namely the population growth rates, expenditure on education, the Gini index and the relatively similar GDP figures.

TABLE 1

COUNTRY PROFILES

\begin{tabular}{|l|l|l|}
\hline & $\begin{array}{c}\text { Republica Federativo do } \\
\text { Brasil }\end{array}$ & \multicolumn{1}{|c|}{$\begin{array}{c}\text { Republic of } \\
\text { South Africa }\end{array}$} \\
\hline Population (2007) & 191 million & 49 million \\
\hline Urban Population (2007) & $85.2 \%$ & $60.2 \%$ \\
\hline Unemployment rate \% of labour force (2008) & 8.2 & 22.9 \\
\hline Population Growth rate (Average annual \%) & 1.0 & 1.0 \\
\hline Education: Government expenditure (\% of GDP) & 5.0 & 5.1 \\
\hline Gini index (2005) & 56.7 & 65 \\
\hline Restored/first democratic election & 1985 & 1994 \\
\hline Gross Domestic Product per capita (2008) & 8311 USD & 5569 USD \\
\hline Number of People living with HIV in 1990 & 300 000 (estimates) & 160 000 (estimates) \\
\hline Number of people living with HIV in 2007 & 730000 (estimates) & 5.7 million (estimates) \\
\hline
\end{tabular}

Sources: United Nations, 2009a \& 2009b. Available from:

http://data.un.org/CountryProfile.aspx?crName=Brazil and

http://data.un.org/CountryProfile.aspx?crName=South\%20Africa [Accessed: 29/01/2009]. 
Brazil and South Africa are emerging powers that are both multi-ethnic and multicultural. Both have a recent legacy of political oppression, with Brazil restoring its democracy in 1985 followed by South Africa achieving its democratic dispensation in 1994. Their interests in collaboration and exerting a global influence converged with those of India and resulted in the Brasilia Declaration, which formalised a co-ordinating body known as India-Brazil-South Africa (IBSA) in 2003 (IBSA, 2010). The members of this tripartite group share common "democratic credentials, their condition as developing nations and their capacity of acting on a global scale...[and]... Their status as middle powers, their common need to address social inequalities within their borders and the existence of consolidated industrial areas in the three countries" (IBSA, 2010).

Brazil's and South Africa's analogous histories, stages of social and economic development and their close ties enabled a comparative analysis. Notwithstanding their similarities, their exceedingly divergent HIV infection rates made this study that much more compelling.

\section{INFECTION RATES}

The infection rates in Brazil and South Africa were, as in most countries, fairly low in 1990. However, the rate of infection increased much more substantially in South Africa than it did in Brazil between 1990 and 2007. In the case of Brazil the infection rate approximated a doubling from an estimated 300000 to an estimated 730000 (UNAIDS, 2008a:5). This increase is presented graphically in Graph 1.

\section{GRAPH 1}

NUMBER OF PEOPLE LIVING WITH HIV IN BRAZIL, 1990-2007

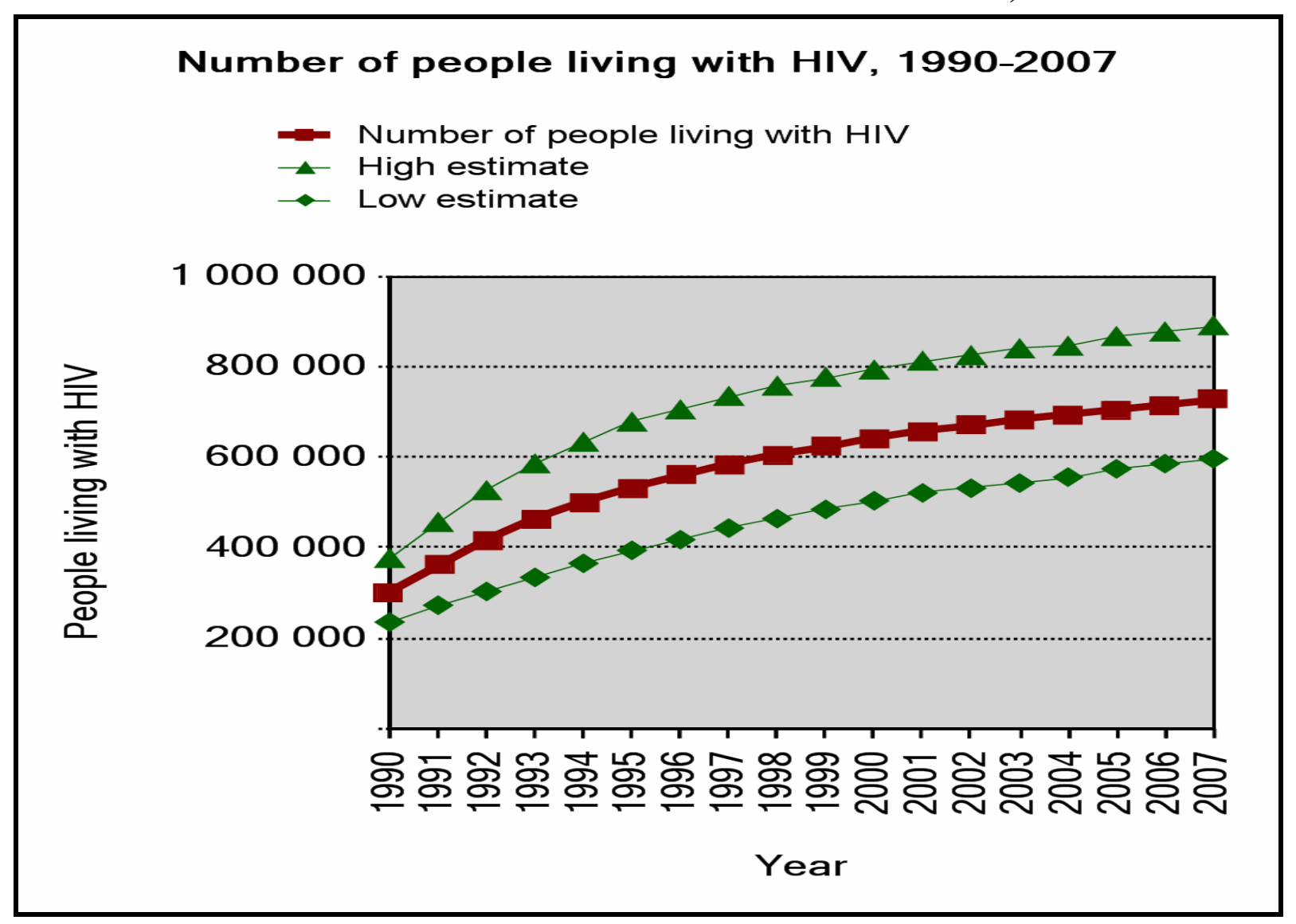

Source: UNAIDS 2008a. Epidemiological Fact Sheet on HIV and AIDS:

Core data on epidemiology and response, Brazil:5. 
Interestingly, the increase in the infection rate did not spiral to double the figure as predicted by Galvao (2002:4), while the World Bank's prediction was that by 2000 Brazil would have 1.2 million people living with HIV/AIDS - it was limited to roughly half that estimate (Pembrey, 2009).

By comparison, the rate of infection in South Africa increased nearly sixfold from an estimated 160000 to an estimated 5700000 (UNAIDS, 2008b:4) and is reflected graphically in Graph 2.

\section{GRAPH 2}

NUMBER OF PEOPLE LIVING WITH HIV IN SOUTH AFRICA, 1990-2007

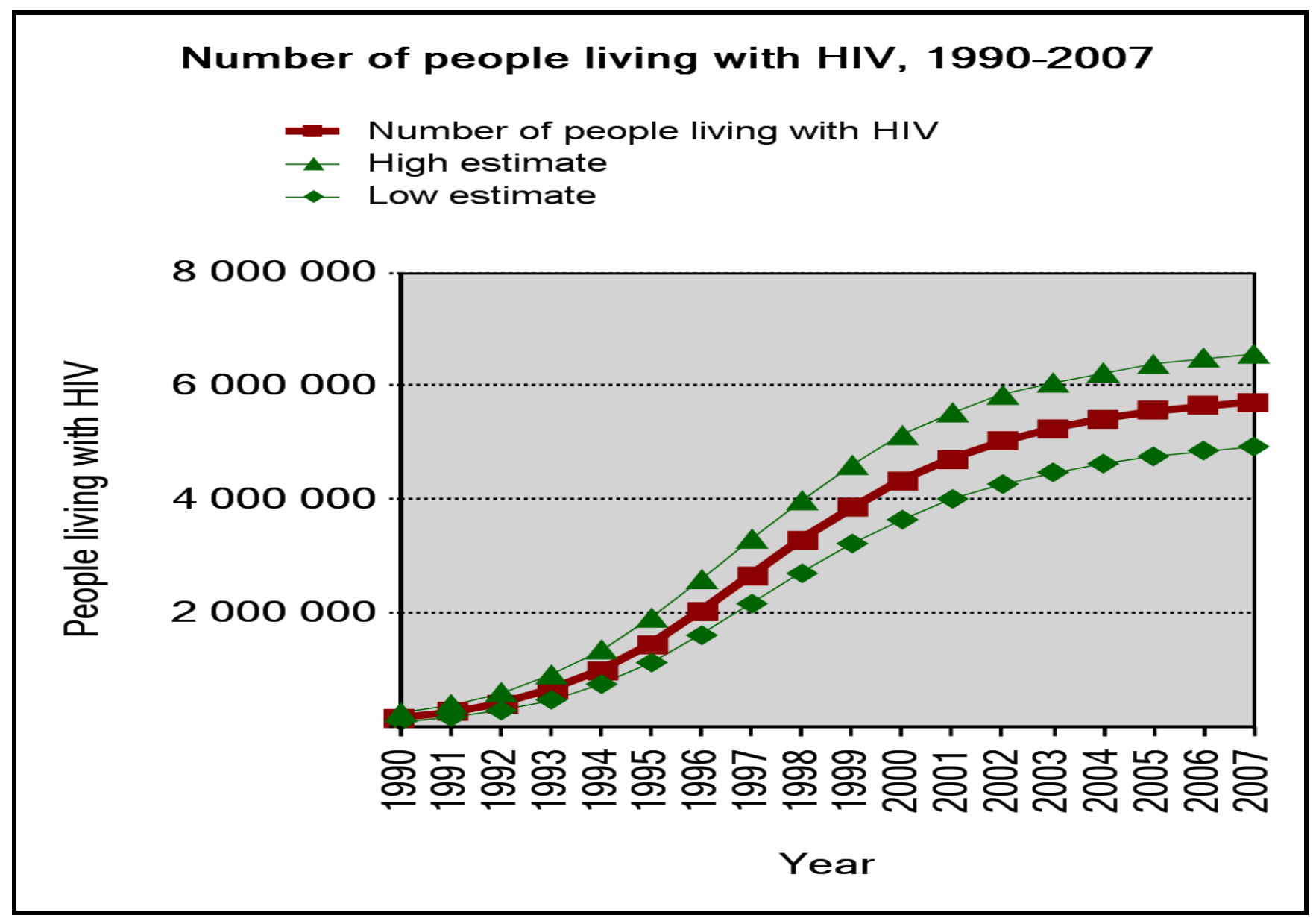

Source: UNAIDS. 2008b. Epidemiological Fact Sheet on HIV and AIDS: Core data on epidemiology and response, South Africa:4.

Clearly Brazil and South Africa had adopted very different intervention strategies that led to the vastly dissimilar rates of infection. Unlike Brazil, where the infection rate started dropping around 1996, the rate increased significantly in South Africa until around 2002 before reflecting a lowering of the rate of infection - some eight years later than that recorded in Brazil. 


\section{STUDY PROCESS}

Given the extremely divergent infection rates, this study set out primarily to:

- comparatively analyse the Brazilian and South African national HIV/AIDS prevention policies;

- determine Brazilian and South African HIV/AIDS non-profit organisation directors' understanding of the respective prevention policies and their construal of the differential in infection rates; and

- determine the nature and role of HIV/AIDS non-profit organisations.

This research analysed both the Brazilian and South African national HIV/AIDS prevention policies that were formulated in response to the illness. These policies were analysed to determine the structures and operations that they promoted and the degree to which these met with success. Being Brazilian and thus conversant with Portuguese, one author could access all Brazilian policies and documents.

Given the sensitive nature of the topic, a qualitative approach was adopted. It relied on a purposive non-probability sample based on populations of directors of HIV/AIDS non-profit organisations based in Sao Paulo and in Cape Town. While these two cities are very similar in many respects, they were chosen for ease of access. The populations consisted of all such organisations listed by the Forum de ONGs AIDS do Estado de Sao Paulo (AIDS NGO Forum of the State of Sao Paulo - listing a total of twelve organisations) and the SANGONET directory which listed ten organisations. Both populations (22 organisations) constituted the purposive sample. Each organisation director (the respondents) was contacted requesting an interview. Of the twelve Brazilian organisations, seven participated (58\%) and of the ten South African organisations, seven respondents (70\%) agreed to be interviewed.

Based on a semi-structured interview schedule, in-depth interviews lasting 90 minutes each were conducted in either Portuguese or English with each of the fourteen respondents. All interviews were electronically recorded and Tesch's framework (Tesch, 1990) and NVivo software were utilised to analyse the content of the transcriptions and to assemble the data.

\section{HIV/AIDS IN BRAZIL}

Brazil first reported a case of HIV/AIDS in 1982 and even though the number of reported cases remained low, civil society was from the very beginning highly vocal in urging the authorities to act and not ignore the spread of the illness. After Brazilian democracy was restored in 1985 after 20 years of repressive military dictatorship, the Programa Nacional de AIDS (National AIDS Programme or NAP) was created in partnership with the civil society. NAP's main purpose was to distribute information on HIV/AIDS, especially for high-risk groups (Ministerio da Saude, 2005).

Homosexual men in Brazil are known as "men who have sex with men" (MSM) and this group accounted for the majority of infections in Brazil at that time. In 1985 the first HIV/AIDS nonprofit organisation was formed known as Grupo de Apoio de Prevencao a AIDS (GAPA) and subsequently many similar organisations were established (Galvao, 2002).

Given successful trials using anti-retroviral drugs (ARVs), civil society pressured government to provide free ARVs and in July 1996 the Brazilian Health Minister announced that ARVs would be provided free to all people living with HIV/AIDS that required them (Galvao, 2002). 
Brazil successfully used public figures to create an awareness of the disease and its prevention. Among these were notably Agenor Miranda Araújo Neto, also known as Cazuza (Brazilian singer), Hebert Jose de Souza, also known as Betinho (Brazilian political activist) and Freddy Mercury (British singer). The disclosure of their HIV status helped to demystify the illness and they actively campaigned against its spread (Merson, O’Malley, Serwadda \& Apisuk, 2008:482).

During the late 1990s the many prevention campaigns that were launched began to stem the tide of infection and, though the World Bank had predicted that by 2000 Brazil would have 1.2 million people living with HIV, it transpired that only half this number did (Pembrey, 2009). By 2006 the mortality rate for AIDS-related illnesses had decreased from 9.6 annual deaths per 100000 population in 1996 to just 6.0 deaths (Pembrey, 2009).

While in Brazil the author noticed there were no widespread Voluntary Testing and Counselling Centres (VTC), which are commonly found in South Africa. This is of concern as Sherr et al. (2007) found that men and women who tested positive reported having fewer sexual partners and higher condom usage once their status was known to them.

Up to 2005 there were 9000 reported cases of mother-to-child transmission in Brazil and while 95 percent of pregnant women in Brazil attended antenatal clinics, only 65 percent of this population had an HIV test and only 52 percent received their results before their children were born (Ministerio da Saude, 2005:12). In the northern and north eastern regions of Brazil these statistics were lower, with only 44 percent of pregnant women being tested during pregnancy of these, only 24 percent got their results before the child was born (Ministerio da Saude, 2005:12).

While Brazil did manage to contain the epidemic nationally, the rate of infection in the povertystricken rural parts of the northern and north-eastern regions of the country remains on the increase - particularly so in the case of women (Pembrey, 2009). Of concern though is the increase in the number of women being infected. For every woman infected during the 19891990 period, two men were infected (Ministerio da Saude, 2005:10). By 1998 the rate had changed to an infection ratio of 10 men to 14 women (Ministerio da Saude, 2005:12).

\section{HIV/AIDS IN SOUTH AFRICA}

As in Brazil, the first diagnosis of HIV/AIDS in South Africa was recorded 1982, when two white homosexual men were diagnosed with the virus. Both men were flight stewards and had visited the United States of America, where the illness was first identified. Initially HIV infections occurred mostly among homosexual men, though by 1985 it was clear that other categories were also being infected, notably drug users. The first black South African, a mine worker, was diagnosed with HIV/AIDS in 1987 (Leake, 2009). Towards the end of the 1980s, as political tensions began easing, more attention was devoted to the emerging HIV/AIDS crisis.

In 1992 the National AIDS Coordinating Committee of South Africa (NACOSA) was formed. NACOSA encouraged all political parties, academics, business organisations, trade unions and other civil society organisations to help raise awareness. NACOSA's strategy was to fight HIV/AIDS on all fronts: prevention, research, human rights, counselling and welfare provision involving a number of government departments. South Africa's National HIV/AIDS Plan was adopted within months of the country's first democratic election in 1994, spurring optimism 
that an epidemic on the scale experienced by other African countries would be avoided as the prevalence rate was still relatively low (Heywood \& Cornell, 1998).

Despite this promising start, the infection rate increased rapidly. Most commonly blamed for this setback was the bureaucratic restructuring of government that resulted in a devolution of power to provincial government level, with the resultant lack of a shared and coherent strategy to combat HIV/AIDS. Similarly, while the national Department of Health announced at the end of 2003 that they would provide ARVs, this only materialised in March 2005 (Leake, 2009).

There were a number of media-based prevention programmes launched over the years, notably the soap operas Soul City and Khomanani, which served to provide information on the disease and to promote condom usage and testing (Leake, 2009). Much money was also spent on the nationwide, though predominantly urban-based "LoveLife" campaign, which was launched in 1999 to reduce teenage pregnancies and sexually transmitted diseases and to offer treatment for HIV/AIDS sufferers (Leake, 2009).

In 2007 the HIV and AIDS and Sexually Transmitted Infection Strategic Plan for South Africa 2007-2011 was launched. Some of the key objectives were to provide ARVs for 80 percent of people living with HIV/AIDS and to reduce infections by 50 percent by 2011 (RSA, 2007:13). However, by the end of 2007 it was estimated that 5.7 million people in South Africa were living with the disease and around 1000 HIV/AIDS-related deaths occurred every day (UNAIDS, 2008b:6).

But South Africa was fortunate in having a very outspoken critic of misguided political approaches to prevention and of government inertia. Zackie Achmat, a co-founder of the Treatment Action Campaign (TAC) in 1988, advocated fearlessly for free treatment for all infected persons and regularly and relentlessly took government to task for its inability to stem the tide of infections and the resultant deaths (Merson et al., 2008). Unlike in Brazil, where many organizations lobbied and campaigned in unison, in South Africa this task was seemingly left mostly to the TAC.

In direct contrast to Brazil, where public figures regularly disclosed their HIV status and so raised awareness, this did not occur in South Africa. Rather, some national leaders minimized the significance of the disease by adopting a "denialist" approach to its causes, espousing odd forms of prevention and treatment, and engaging in risky behaviour, all contrary to what was being advocated by experts in the field.

More recently, scientifically proven prevention measures have added to the country's arsenal of prevention. One such measure adopted by South Africa was male circumcision - the World Health Organisation (2007:3) reported that a circumcision performed by a well-trained doctor could reduce the risk of a male being infected by up to 60 percent. Similarly, Williams et al. (2006:4) reported that if 35 percent of the male population aged between 15 and 45 years were circumcised, it could prevent 174000 infections annually.

Furthermore, South African scientists Salim and Abdool Karim recently developed the first microbicidal vaginal gel for women, which in medical trials indicated a reduction of women being infected by up to 39 percent (Besheer, 2010).

\section{Policy differences}

While there were many similarities in their respective prevention policies, there are a few major differences that could well have contributed to the very differing infection rates recorded by the two countries. 
While both policies articulate their respective country's goals, the Brazilian policy, unlike that of South Africa, contains a detailed action plan for the attainment of each goal it articulated.

The Brazilian policy reflects the importance of decentralisation of power and resources to state (provincial) and municipal levels to better address the geographic differences that pertain to HIV/AIDS. In South Africa decentralisation only appeared much later in the 2007 Strategic Plan and then only to provincial levels. There are, however, currently attempts to include activities at local government level.

In Brazil civil society contributed significantly to the formulation of national policy and it remains very active in its implementation. This partnership was confirmed by a Brazilian respondent in stating that:

We also put some pressure, and they always bring it to us. We no longer accept them doing the policy by themselves; either we build together or we do not participate at all, but if we don't participate in building the policy, then we won't follow it as well...

This was not the case in South Africa - civil society was not very active in policy formulation and is not actively engaged in its implementation. This view was confirmed by a South African respondent who stated that:

Unfortunately I don't think, I think the only organisation that has any influence on the government is TAC...

A civil society/government partnership is pivotal to policy formulation that accurately reflects the issues experienced by the populace. In Brazil all respondents were very familiar with past and current policies, specifically because of their involvement in their formulation. This was confirmed by a Brazilian respondent who stated that:

Well, every policy is developed at the Articulation Committee of the social movements and the National committee of AIDS; we discuss everything there, so the policy is made in conjunction.

In contrast, only two South African respondents demonstrated knowledge of past and current policies, reflecting the lack of civil society participation in policy formulation. This view was articulated by a South African respondent as follows:

I don't know much at all about it; there has never been anything from the government to inform us about the plan.

Central to both the Brazilian and the South African national strategic plans was the countrywide distribution of millions of condoms as well as media campaigns to promote condom use as an effective prophylactic. However, while Brazil has remained largely focused on condom usage as the main method of prevention, South Africa adopted other methods including male circumcision, addressing the risk of multi-concurrent partners and the economic status of women.

\section{SPREAD OF DISEASE IN BRAZIL}

Five of the seven Brazilian respondents indicated that the rapid spread of the disease between 1990 and 1996 was a result of a lack of knowledge of the illness and its transmission. It was also related to the lack of medical breakthroughs and effective organisation to counter the spread of the epidemic. This collective view was expressed by a respondent as follows: 
I believe it is a period of discoveries, I think the epidemic process and the discoveries of $A R V$, the discoveries in the medical field, also the time for everyone to organise themselves, for the social movement to build this power, I think it takes time.

This concurs with the view of Merson et al. (2008), who stated that because it was a relatively new and unknown disease, this created a host of misconceptions which fuelled the increasing prevalence of the disease.

Clearly the advent of ARV treatment signalled the turning point in the rates of infection. Six of the seven Brazilian respondents stated that the introduction of ARVs after 1996 stabilised the infection rate (see Graph 1), as reflected by the following response:

The main reason for the stabilisation was the introduction of ARVs in 96 and increased the quality of life of people.

In Brazil all respondents attributed the government's rapid response to HIV/AIDS to pressure applied by civil society in the form of large and widespread protests and marches, as reflected by the following statement:

I think it was the fight from the AIDS NGOs and the civil society, the NGOs fought a lot so the human rights could be addressed...

Six indicated that by the early 1990s the Brazilian government had embraced the issue seriously and they felt that the government was currently sufficiently attentive of the issue, thanks chiefly to pressure from civil society then and now.

While all Brazilian respondents agreed that the best future prevention methods should continue to be on-going education programmes and greater distribution of condoms, they were not very optimistic about the future decline of HIV/AIDS. Five respondents thought that the prevalence rate would not drop within the next fifteen years, while two respondents thought it would increase. They mentioned that the population was not as careful as before, because of the efficiency of ARVs, though the majority were not aware of the side effects - the prevailing attitude was that if one contracted the disease, one could live a healthy life thanks to ARVs. This view was echoed by one respondent, who stated that:

Well I think it is going to go up, if we carry on the way we are it is going to go up, I think it is going to go up because if we get the young population that was born during the pandemic, and born when the treatment already existed, they have not experienced the devastation of HIV in Brazil and in the world, so I think this will make the numbers go up significantly of people infected in Brazil.

Furthermore, their reasons for this lack of optimism were premised on the current prevention policy, which is skewed heavily in favour of condom usage to the exclusion of other methods such as inter alia addressing the low economic status of women and male circumcision. Dorothea and Coetzee (2004) argued that gender inequality makes women more vulnerable to infection than men as their low status often precludes them from deciding who to have intercourse with and what prophylactics to use. This is particularly so in the poorer rural areas.

Another reason for their pessimistic outlook was the notion that after two decades of advocating safe sexual behaviour, there is a very palpable "HIV/AIDS fatigue syndrome", where people are tired of the issue and have begun focusing on other more immediate threats, such as other illnesses and the economy. A Brazilian respondent summed up the views of the six others by stating that: 
I think that in the general public it does not have the same importance as it had in the 90 s and 80s; it is not as important; today there are other epidemics which are more debated, which has more value in Brazilian society.

Goodroad, Kirksey and Butensky (2000) also concluded that people have grown tired of years of abstinence, limited sexual activity, condom use and constant chiding by government and the media. This, together with the efficacy of ARV treatment and the increasing misconception that ARVs ensure a normal and healthy lifestyle, increasingly works against adopting safe sexual practices (Cassel \& Halperin, 2006). This has led to an increase in sexual intercourse without using any form of protection, condomless intercourse known as "barebacking" being an example (Bouer, 2002). More worryingly, Goodroad et al. (2000) report on "bareback" parties attended by both infected and non-infected sexual partners, where the intention is that coitus with infected persons could occur by chance, thus not only providing sexual pleasure but also producing an adrenaline rush at the possibility of being infected. Three respondents concurred with these views:

I see that people think it is not as important, many groups have left the prevention field, and the tactic of safe sex, because they think there are drugs, they think that if you take the drugs before sex, you have intercourse without using a condom and even if the partner is infected you won't get it because they think they have prevented because they took the drugs, which is absurd.

\section{SPREAD OF DISEASE IN SOUTH AFRICA}

The majority view held by five South African respondents was that during the 1990-1996 period attention was focused almost solely on political reform and hence little attention was devoted to HIV/AIDS. A respondent summarised this as follows:

South Africa before 1994 was obliviously going through turbulent times amongst the population and during that time HIV did not play a major role in the politics and maybe it was ignored for too long.

From 1997 onwards South Africa experienced a significant increase in the HIV infection rate see Graph 2. Five of the respondents attributed this to a resurgence of the disease because of the significant number of people who tested positive and the rapid increase in related deaths - the assumption was that they had been infected in previous years but were only diagnosed after 1996. This view was articulated as follows:

In between 1996 and 2003 I think it was when we got a larger number of deaths, I would say because of the increments in the beginning you know I have seen a lot of babies getting sick and dying, there wasn't enough awareness I think the number were just so great and overwhelming, most probably they got infected way back then but it only started manifesting here, also because of the stigma as well.

Another theory for this dramatic increase was postulated by Ajala and Adejumo (2007), who claimed that the stigma of the illness drove many rural dwellers to seek treatment in the more anonymous and better equipped urban areas, where they swelled the ranks of those diagnosed with the illness.

In keeping with Fassin and Schneider's (2003) view that misguided and contradictory political pronouncements resulted in increased infection rates, some respondents linked the increase to these conflicting political stances on the illness. All respondents said that little was forthcoming 
from government during the 1990s and most indicated that government's response to the issue came much later - this was confirmed by a respondent who stated that:

Well they didn't do anything from 1990 to 1999. I will say, there wasn't much of an effort done in regards to...when was the ARV? I think in 99. We know that our government was very slow in responding to HIV and you most probably know that Thabo Mbeki was one of the biggest AIDS “denialist" out there.

After 2003 the infection rates began to ease and respondents attributed this to the distribution of ARVs and continued prevention programmes. While education was rated as the best method of prevention, other methods were beginning to emerge in importance as reflected by a respondent who stated that:

I think probably voluntary counselling and testing and behaviour change campaign, general awareness campaign, but focusing on multiple concurrent partners hmm men that have sex with men, women and youth, sort of teenagers, focusing on the vulnerable group will be definitely most important.

Six respondents were of the opinion that currently the government does not yet pay enough attention to the issue, though five thought that the government's response was improving. All respondents mentioned that the Treatment Action Campaign was the only effective voice against government lethargy, as indicated by the following response:

TAC is the strongest organisation that really made a lot of noise, a lot of progress in terms of ARV roll-out and the attention from international media to South Africa to put pressure on government to change their opinion and policies.

All South African respondents were more optimistic about the future decline in infection rates than were their Brazilian counterparts. This buoyancy was predicated on South Africa embracing newer preventive measures and not relying solely on condom usage. Though optimistic, they all also echoed the concerns about "HIV/AIDS fatigue syndrome" raised by their Brazilian counterparts as follows:

Yeah, especially the younger kids and the teenagers are very tired of the topic, there are many campaigns like LoveLife and so on and the children are very tired because they think, look there is another one talking about HIV and they think they know everything about it and they can't hear any more. And also know they are thinking because of the ARV, oh no problem because there are medications, so it is fine we don't have to worry about it.

\section{HIV/AIDS NON-PROFIT ORGANISATIONS}

Once again, while there were similarities in terms of non-profit organisations, a number of important differences emerged. In Brazil the respondents were well known to each other, often enquiring whether the researcher had interviewed, or would be interviewing, other respondents known to them. In South Africa, though, most respondents were not acquainted with each other. This knowledge of each other's operations in Brazil fostered co-operation, eliminated duplication and significantly strengthened lobbying and endeavours aimed at taking government to task.

Brazilian organisations were much less dependent on government funding than was the case in South Africa. In Brazil only two of the seven organisations received money from the government - in just one case did this constitute just over 50 percent of the organisation's total 
income. Notably, the remaining five organisations were vociferous in their view that no government funding should be accepted as this compromised their autonomy. This left them free to criticize the government without fear of reprisal. This view is exemplified by the following response:

Look I am against this government funding in a way, I think that civil organisations must have autonomy so it can demand because from the moment that the government finance all your actions how are you going to complain about your funder, so it becomes a bit limited.

In South Africa double the number, four out of the seven organisations, received funding from the government, though only one organization received more than 50 percent of its income from the government. By accepting funding from the government, these organisations may feel financially vulnerable when required to question the government's policies and/or actions.

Interestingly, while none of the Brazilian organisations received foreign funding, all the South African organisations did. In addition to all Brazilian organisations relying on proposal writing to generate income, five organisations also had other means of fundraising. In contrast, while all South African organisations also relied on proposal writing, only one organisation had an alternative means of generating revenue.

The South African dependence on government and foreign funding limited these organisations' autonomy and their ability to challenge current HIV/AIDS policy and practices. This concurs with the view put forward by Julie (2009), who states that many South African non-profit organisations have became too dependent on external and government funding, and have done little to safeguard their independence.

\section{COMPARATIVE SUMMARY AND TENTATIVE COUNSEL}

In juxtaposing the spread of HIV and government responses in Brazil and South Africa, a number of significant differences emerged in terms of the countries' respective approaches to the prevention of the spread of HIV - these are summarised in Table 2.

TABLE 2

SUMMARY OF DIFFERENCES IN APPROACH TO HIV/AIDS PREVENTION

\begin{tabular}{|l|l|}
\hline \multicolumn{1}{|c|}{ Republica Federativo do Brasil } & \multicolumn{1}{c|}{ Republic of South Africa } \\
\hline Extensive political commitment & Limited political commitment \\
\hline Policy has clear action plans & Policy does not have action plans \\
\hline Decentralised policy & Largely centralised policy \\
\hline Extensive civil society influence & Limited civil society influence \\
\hline Distributed ARVs from 1996 & Distributed ARVs from 2005 \\
\hline $\begin{array}{l}\text { Extensive civil society advocacy } \\
\text { and input on policy formulation }\end{array}$ & $\begin{array}{l}\text { Limited civil society advocacy and } \\
\text { input on policy formulation }\end{array}$ \\
\hline Condom use main prevention & Condom use and other approaches \\
\hline $\begin{array}{l}\text { Limited non-profits dependence on } \\
\text { foreign and government funding }\end{array}$ & $\begin{array}{l}\text { Extensive non-profits dependence on } \\
\text { foreign and government funding }\end{array}$ \\
\hline Extensive non-profits co-operation & Limited non-profits co-operation \\
\hline
\end{tabular}


Based on the findings of this study a limited number of recommendations are proffered for Brazil and South Africa. Despite their very different respective HIV/AIDS histories, both countries can benefit from each other's experiences.

Brazil relies heavily on condom use and should explore other methods of prevention. As circumcision is not widespread in Brazil, this is an option that could be explored. Given that the rates of infection are increasing among women in the rural areas of the northern and northeastern regions, serious consideration should be given to addressing the gender inequality and poverty that these women encounter.

Another approach could be to target multi-concurrent partnerships, including the not too uncommon practice of men having sex with men. This is critical, given the prevailing attitude that the introduction of ARV treatment has replaced the need to practice routine safe sex. This gives rise to another important policy directive - better and more extensive dissemination of information on the nature of ARVs and their effect on the human body to debunk the myth that they are harmless.

Brazil could benefit from the establishment of more Voluntary Testing and Counselling Centres, which could conceivably be done in tandem with their very successful and widespread vaccination programmes. Greater testing of pregnant women would also reduce mother-to-child transmission. Given the significant impact that the media has on Brazilian life, the government and other HIV/AIDS campaigners could well further exploit this form of communication.

South Africa has paid a very high price for its initial inaction, obfuscation and "denialist" approach to the disease. A number of lessons could be learnt from the Brazilian experience. The government should embrace, rather than reject, constructive civil society overtures that could both inform policy and improve service delivery. Far wider canvassing of civil society organisations' input in policy formulation should occur and every effort should be made to secure their participation in implementing policy.

The government must revise all its policy and service delivery initiatives to ensure that they are clearly articulated and reflect a decentralised approach to implementation. The necessary structural and fiscal support must be provided to all participating levels of government and, where appropriate, to the non-profit organisation sector. It should be recognised that the disciplines of policy formulation, programme design and management all require advanced degrees of comprehension and proficiency. Furthermore, government should also encourage the country's leadership of all sectors to adopt a more responsible and united view of the illness and its prevention.

Though multi-concurrent partnerships are frowned upon in most parts of the world, the practice is not that uncommon in South Africa. As such, every effort should be made to warn people of the risks inherent in this behaviour. Lest South Africans also begin adopting the attitude that ARVs are the panacea, campaigns on their nature and side-effects should be launched. Given the recent research finding that circumcision reduces the risk of infection and the relatively large number of male circumcisions that occur in South Africa, the view that it alone is sufficient to prevent infection should be vigorously countered.

HIV/AIDS non-profit organisations should, like their Brazilian counterparts, more vociferously influence national debates and policy initiatives. This can be done more effectively if they wean themselves from funding sources that constrain this form of desired behaviour. Organisations will also be helped in this role, if they were working together in more functional partnerships. 


\section{CONCLUSION}

Improvident political thinking and government ineptitude can never be condoned, particularly when this results in the loss of human lives. When the disease struck, Brazil and many other countries acted responsibly. South Africa did not, thus sentencing thousands to death and countless others to a life of woe.

This study attests that politicians and governments are not always good at discerning what their countries need. Throughout the nations of the world where the collective will of civil society is resolute, the welfare of the nation is assured.

Notwithstanding the successes and failures recorded by both Brazil and South Africa, there is mounting evidence that history and its lessons are beginning to influence future endeavours. May we never again allow unpardonable political dictates to sustain such a lamentable affliction.

\section{BIBLIOGRAPHY}

AJALA, A. \& ADEJUMO, P. 2007. Cultural determinants of care and support for people living with AIDS in Yoruba Communities of Ibadan and Ilesa Nigeria. The Journal of HIV/AIDS \& Social Services, 6:83-104.

BESHEER, M. 2010. AIDS Conference wraps up in Vienna. [Online] Available: http://www.voanews.com/english/news/AIDS-Conference-Wraps-Up-in-Vienna-9910

3004.html [Accessed: 26/08/2010].

BOUER, J. 2002. Sexo inseguro é motivo de debate entre os jovens. Sao Paulo: Folha de Sao Paulo.

CASSELL, M. \& HALPERIN, D. 2006. HIV and risk behaviour: risk compensation: the Achilles' heel of innovations in HIV prevention? British Medical Journal, 32:605-612.

DOROTHEA, P. \& COETZEE, H. 2004. Identity development of South African adolescents in a democratic society. Journal of the South African Sociological Association, 35:183-193.

FASSIN, D. \& SCHNEIDER, H. 2003. The politics of AIDS in South Africa: beyond the controversies. British Medical Journal, 326:495-503.

GALVAO, J. 2002. 1980-2001 Uma Cronologia da Epidemia de HIV/AIDS no Brasil e no Mundo. Politicas publicas No 2. Rio de Janeiro: Associacao Brasileira Iterdisiplinar de AIDS.

GOODROAD, B., KIRKSEY, K. \& BUTENSKY, E. 2000. Bareback sex and gay men: an HIV prevention failure. Journal of the Association of Nurses in AIDS Care, 11:29-36.

HEYWOOD, M. \& CORNELL, M. 1998. Human rights and AIDS in South Africa: from right margin to left margin. Health and Human Rights, 2:60-82.

IBSA - INDIA-BRAZIL-SOUTH AFRICA. 2010. [Online] Available: http://www.ibsatrilateral.org/ [Accessed: 13/09/2010].

JULIE, F. 2009. The roots of the NGO crisis in South Africa: a look beyond the surface. Cape Town: Creda Communications.

LEAKE, M. 2009. History of HIV\&AIDS in South Africa. HIV and AIDS information. [Online] Available: http://www.avert.org/history-aids-south-africa.htm [Accessed: 29/01/2009].

MERSON, M., O’MALlEY, J., SERWADDA, D. \& APISUK, C. 2008. The history and challenge of HIV prevention. The Lancet, 372:475-488. 
MINISTERIO da SAUDE. 2005. Plano Estrategico Programa Nacional de DST e AIDS 2005. Brazilia: Ministerio da Saude.

PARKER, R. 2009. Civil society, political mobilization and the impact of HIV Scale-UP on health system in Brazil. Acquired Immune Deficiency Syndrome, 52:S49-S51.

PEMBREY, G. 2009. History of HIV\&AIDS in Brazil. HIV and AIDS information. [Online] Available: http://www.avert.org/aids-brazil.htm [Accessed: 28/01/2009].

RSA - REPUBLIC OF SOUTH AFRICA. 2007. HIV and AIDS and STI Strategic Plan for South Africa, 2007-2011. Department of Health. Pretoria: Government Press.

SHERR, L., LOPMAN, B., KAKOWA, M., DUBE, S., CHAWIRA, G., NYAMUKAPA, C., OBERZAUCHER, N., CREMIN, I. \& GREGSON, S. 2007. Voluntary counseling and testing: uptake, impact on sexual behaviour, and HIV incidence in a rural Zimbabwean cohort. Official Journal of the International AIDS Society, 21:851-860.

TESCH, R. 1990. Qualitative research: analysis types and software tools. London: Routledge-Falmer.

UNAIDS. 2008a. Epidemiological Fact Sheet on HIV and AIDS: core data on epidemiology and response, Brazil. [Online] Available: http://apps.who.int/globalatlas/ predefinedReports/EFS2008/full/EFS2008 BR.pdf [Accessed: 28/01/2009].

UNAIDS. 2008b. Epidemiological Fact Sheet on HIV and AIDS: core data on epidemiology and response, South Africa. [Online] Available: http://apps.who.int/ globalatlas/predefinedReports/EFS2008/full/EFS2008_ZA.pdf [Accessed: 28/01/2009].

UNITED NATIONS. 2009a. Brazil. [Online] Available: http://data.un.org/CountryProfile. aspx? crName $=$ Brazil [Accessed: 29/01/2009].

UNITED NATIONS. 2009b. South Africa. [Online] Available: http://data.un.org/Country Profile .aspx ?crName=South\%20Africa [Accessed: 29/01/2009].

WILLIAMS, B., LLOYD-SMITH, J., GOUWS, E., HANKINS, C., GETZ, W., HARGROVE, J., DE ZOYSA, I., DYEL, C. \& AUVERT, B. 2006. The potential impact of male circumcision on HIV in Sub-Saharan Africa. Plos Medicine, 3:1-9.

WORLD HEALTH ORGANISATION. 2007. New data on male circumcision and HIV prevention: policy and programme implication. [Online] Available: http://www.who.int/ hiv/mediacentre/MCrecommendations en.pdf [Accessed: 26/08/2010].

Mr Rafael Noronha, Development Officer: Rural Education, Awareness and Community Health Organisation, Cape Town, South Africa; Prof André de V Smit, Department of Social Development, University of Cape Town, Cape Town, South Africa. 